\title{
Female Violence and Crime in Brazil from Interdisciplinary Perspective
}

\author{
Kátia Ovídia José de Souza
}

National School of Public Health Sergio Arouca, Oswaldo Cruz Foundation, Street Leopoldo Bulhões, 1480, Manguinhos, Rio de Janeiro, RJ, Brazil

katiaovidia@oi.com.br

\begin{abstract}
Between the studies about gender and maritalviolence, the focus is more on wo men as victims of vio lence. Th is situation is important, but based on a theoretical discussion with authors of the health and sociology health field during the decade 2000, this article aims to investigate the feminine violence. In the literature about gender violence, there are few studies about the visibility of the woman as author of violent acts, specifically, drug trafficking, the main reason for the imprisonment of wo man in recent years in Brazil, and contributing to the increase in rates of the wo man as author of violent acts. Thereby, this article tries to contribute with more enlightenment about feminine violence, a theme which is not much discussed between Brazilian authors.
\end{abstract}

Keywords Violence, Delinquency of Women, Drug Trafficking

\section{Introduction}

"Violence is a socio-historical phenomenon and follows the whole experience of humanity", a social and public health problem, with effects on individual and collective health that need attention and intervention measures[1]. Gender violence is an expression of the type of violence that includes: a violent act perpetrated by men against women, by wo men against men, among men and women[2]. The emphas is in studies of gender-based violence is violence against wo men, she being the victim of various forms of oppression, domination and aggression by physical, psychological, social and sexual.

Very little has been researched over the woman as the author of acts of violence. Several authors supporting the view that has been attributed little or no value to female violence[3-11].

Rare are the books and debates that include wo men as the author of crimes. If anything, the criminological literature or novels, women are treated as co-author, architect or an accomplice of crimes, and rarely as the creator of her crime[3].

Most studies on gender violence[11] emphasizes more violence against women associated with domestic violence, naming the violence as constitutive of masculinity, that is, "Much of the author analyzes the problem from one-way, the direction of the violence of man for wo man"[6].

The most apparent reasons for the poor visibility or even

* Corresponding author:

katiaovidia@oi.com.br (Kátia Ovídia José de Souza)

Published online at http//journal.sapub.org/jipbs

Copyright (C) 2012 Scientific \& Academic Publishing. All Rights Reserved the absence of studies on female violence are: low incidence crimes of female authorship, compared to the crimes of male authors; the course is not apparent or concealment of female violence; the mode of participation in crime; lower recidivism to crime in comparison with males; legally irrelevant to criminal involvement; low reporting of female crimes; the prejudice of the people, who attach little or no value to the manifestations of female violence; lack of public pressure, which is not interested in the topic; the discrimination of public and police; and discrimination by the legislature and the judiciary $[4,5,9,12]$.

Nevertheless, Brazilian statistics about women prisoners, obtained from the Ministry of Justice and the National Penitentiary Department, in the year 2001 (with 5465 prisoners), 2004 (with 16,473 prisoners) and 2005 (with 12,925 prisoners), there was an increase the women in Brazilian prison[10]. In 2005, there were 12,925 prisoners in Brazil, while vacancy rates were 7836 , which translated into a deficit of 5,089 vacancies[9]. Statistical data were found about Southeast of Brazil (Rio de Janeiro, São Paulo and Espírito Santo) for the number of women incarcerated, with the exception of the State of Minas Gerais.

In São Paulo, based on data from the Department of Corrections of April/2004, shows the increasing scale of 1988, with 235 wo men prisoners, the year 2004, with 2984 wo men prisoners[13]. As a source to the IBGE, the Min istry of Justice/DEPEN and the Secretariat of Penitentiary Admin istration of São Paulo, in 1950 there were 30 wo men prisoners between the total of 1,145 prison in mates in Sao Paulo, while in 2006 there were 6077 women prisoners of the total 130,391 people incarcerated in Sao Paulo[10]. In São Paulo to be responsible for concentrating $30 \%$ of the total arrested 
in Brazil[13]. In 2005 the State of São Pau lo had the largest number of prisoners in closed regime (3375 women), half open (450 wo men) and security measures and treatment ( 78 wo men)[9].

In Rio de Janeiro, increase crimes committed by women, based on data from the Department of Prisons from 1995 to 1999: in 1995 there were 381 wo men prisoners to 9144 men prisoners and 1999 with 585 wo men prisoner against 14,036 men prisoner. Regardless of whether the offender is male or female, drug trafficking stands as the main crime committed in 1998[4]. According to the National Bureau of Prisons (DEPEN), the female prison population in 2000 reached 633 wo men. Between 1988 and 2000 there was a 132\% increase in the number of women prisoners, $36 \%$ higher than the increasing number of prisoners men in the same period. The female rate (number of prey on each one hundred thousand women) increased $85.5 \%$ and male, $58.1 \%$, so that the female rate of increase would be $27 \%$ higher than the male. Nevertheless, the number of women prisoners is small compared to men trapped; this growth translates $132 \%$ in 360 wo men prisoners, while $96 \%$ of in mates male represent an increase of 7974 men[5].

In the state of Espírito Santo, based on data from the National Penitentiary Department, the population of women prisoners in 1995 was $1.4 \%$ of the total, in 2004 reached 5\% of the prison population in the state. In 1995 there were 25 women prisoners and in 2004 the number of women prisoners increase to 195[7].

Even with a rate much lower than male rates, the authors agree on the female prison growth. Needs attention the speed of evolution of female violence in recent years, which is greater than the rate of increase in male violence. Looking the data of the General Affairs Correctional DEPEN the MJ-December 2005, the evolution of crimes committed by wo men in the period 2001-2005 was $24 \%$, while the crimes committed by men was $21 \%$ in the same period[9].

Given this reality, this article aims to investigate female violence. In the literature on gender violence by Brazilian authors of health and health sociology of the 2000s, there is little visibility of female violence, or the woman as the author of acts of violence, especially in relation to drug trafficking, the main reason imprisonment of women in recent decades. Drug trafficking is considered a crime by the Brazilian Penal Code. An example is the Law 11343 of August 23, 2006, regarding the National System of Public Policies on Drugs, which, in chapter II, art. 33, defines as crimes: import, export, send, prepare, produce, manufacture, purchase, sell, expose for sale, offer, provide, storing, transporting, bring, keep, prescribe, administer, deliver or provide consumer drugs, even for free, without authorization or in violation of the law or regulation.

The topic addressed in the paper is female violence and crime from interdisciplinary perspective, including psychology, gender studies, cultural studies, sociology and criminology. This paper is based on the literature review. We try to illu minate of some academically marginalized aspects, as silenced female violence.

\section{Woman as Victim}

As was explained earlier in this article, is not the purpose of this study to analyze violence against wo men, but some authors, in a cross-sectional analysis, address the issue of female violence and justify the low visibility of women precisely because it is more identified as victims (those who suffer violence). There is a process of victimization of wo men, she being labeled as a victim without basic rights, as the right to life, safety and welfare.

The studies of some authors $[3,4,6,9,10,13-22]$ argue that the absence or invisibility of female violence should be caused for social control of patriarchal society exe rcised over the female and the bipolarity of public-private space. These assumptions are related to the context of women and violence, the spotlight on the relationship of the marital violence.

The characterization of wo men as weak, submissive, passive, educated to be mother, with sexual repression, based on the model of Mary, a deified image of wo man and unable to be violent, would be dictated by patriarchal normative prescription, in order to maintain male dominance over females, socially legitimated[21].

Through motherhood the man "fix" the woman of his origin sinful Eve Remnants. This thinking can still be found in idea of the menstrual colic's of the wo man will be passed when she be married, because the man will calm the wo man's uterus and make her mother of his children[3].

Thus, man would have rights over women and an honor to uphold, which could be exp ressed through the domestication of women through violence, ensuring his honor male whose masculinity is associated with dominant power. The one-sided perspective of the characterization of man as the aggressor and the woman as victim causes a

Naturalization of hegemonic gender roles, involves the appointment of prescribers as social behavior, damaging both the woman and man. Both are under pressure to conform to such roles, while wo man is taken to the private area, without power and have her repressed sexuality, man is constantly identify ing himself with masculinity and manliness, being unable to fully experience affective experiences[22].

Men and women play a pre-set according to gender roles socially agreed. The female violence is still seen as pathology, because the violent behavior of wo men being is labeled as inappropriate and not femin ine[4].

The main ideologue of women's prisons in Brazil was Lemos de Brito. The first women's prison was built in Rio de Janeiro in 1942, designed to assure the desired peace and tranquility in male prisons, hitherto shared by men and wo men. The religious congregation was of great importance in female prisons, the religious congregation worked to help the domestication woman through of the constant vigilance of her se xuality [5].

The man in prison was recovered for to be "citizens" and reintegrated into the community. While woman in prison was recovered for to be housewife, restored to occupy a 
home and her family, cooking for her husband and give education to children, was her destination[13].

The wo man duty was ensure the care of the household, by the exerc ise of home chores and caring for the children while the man was dedicated to public space, social life and business [3]. This dichotomy of the public/private space is related to the type of violence committed by men, prevailing mortality from external causes, while women suffer more physicaland sexual violence. So men get involved more with violence and urban crime, and women with domestic conflicts. Statistics show, according to 1999 data from the Civil Police of the State of Rio de Janeiro, that the practice of murder by men was $81.1 \%$, and the wo men, $8.4 \%$. The same source data, $59.3 \%$ of co mpla ints by intentional injuries were wo men and $35.7 \%$ of men. These data indicate that men are more affected by violence in the form of homicides, while wo men are more affected in relation to morbidity (impairment of health due to violence), centering the focus on violence directed at wo men in the private space[17].

Men are portrayed as villains and victims. There was the proportion of 12 men deaths for one wo man death, and man can be villains in relation violence against woman. In a survey in 2005, 43\% wo men reported having experienced violence by man during his lifetimes, 33\% some form of physical violence, $13 \%$ sexual violence and $27 \%$ psychological[11].

Contrary to the traditional family (mother, father and children) and domestic violence against women, we need recognize and remember the existence of violent relationships between gay couples and in heterosexual relationships which the woman is the main aggressor[22].

\section{Reversal of the Position of Victim (Passive) for the Aggressive (Violent)}

At the turn of the twentieth century, female violence was attributed the influence of physiological state in wo man life: puberty, menstruation, menopause and childbirth - that is, the influences related to sexuality and motherhood[5]. The incarcerated women deny this myth of female deified, becomes its antithesis, the shadow of the holy woman and mother, and the act of violence becomes a way to break boundaries [3, 10].

Breaking this paradig $\mathrm{m}$, the inclusion of wo man in public spaces, the woman search for autonomy, transform the patriarchal order, finally, women's empowerment, wage labor and the struggles for citizenship fro $\mathrm{m}$ femin ist movements in 1960 and 1970. More than one an integration of woman in public space was confront with patriarchal order. The female transgression would be an escape, a way to demonstrate her dissatisfaction and questioning the sexist structure[3].

Woman have long been represented and representatives of the quiet figure, dedicated to romantic love and housewife, as incapable criminal of committing crimes. Woman rebels against the woman status that had been imposed over the centuries, as well as against cruelty, against submission and also against the underestimation of her ability to commit a crime [3].

The woman, through violence, gets talking, leave the private space. By committing an act of violence, she likes any other criminal. Nevertheless, female violence is seen as an exception to the stereotype of female chastity, for being an action in public space with a new kind of woman to be presented to society, which is outside the model stig matized as good mother, gentle and hous ewife[3].

\section{Women in Drug Trafficking}

The problem of drug trafficking today is growing; their authors can be man or wo man. Drug trafficking has become one of the central problems of violence in Brazil, especially in large urban centers in the Southeast. The violence as sociated with drug trafficking is expressed in constant conflict, with cons equent repercus sions on security and quality of life. It does increase the morbidity and mortality from external causes, which, in turn, force the health sector, with the victims of urban violence who come to emergency departments of hospitals and the need for specialized care and physical rehabilitation and psychological.

The criminality and delinquency are violence and a penal infraction- respectively, crime and penal misdemeanor. The penal misdemeanor is the violation of a penal norm minor at the discretion of the legislature, also called "crime dwarf". The concepts of crime vary with time and space, being a social phenomenon. The crime, in its broadest sense, in the legal point of $\mathrm{v}$ iew, it is human conduct (action or omission) that violates the penal law. Crime comes from the Lat in Crimen (accusation, complaint, grievance, injury), and generally means any action, committed with intent or negligence, contrary to the customs, morals and law[3].

The delinquency begins to be regarded as a breach of the individual's relationship with his social space. The delict word, derived from the Lat in delictum of delinquere, is, in general, applied to mean or imply any unlawful act. Thus, delict is a generic scope while crime and misdemeanor are species. This reason, the delict is shown an act that violates or offends the laws or ordinances instituted by our law. It has wider significance than the crime, which is defined as human action or inaction anti-law, typical, guilty and punishable, or willful or negligent conduct that violates the criminal law and is punishable. There isn't in the Criminal Law Brazilian distinction between crime and delict, such expressions used as synonyms. Thus, punishable fact is the designation broader, encompassing crime (or de lict) and misdemeanor, which are distinct species of delict.

At the beginning of the twentieth century women were characterized author of crimes as induced abortion for reasons of honor and infanticide by psychic crisis puerperal background, crimes associated with motherhood. Prostitution and sexuality to non-reproductive was crime because could endanger the morals and family[5]. 
The crimes committed by women were hardly detectable due to the nature of the offens es, for example, poisoning, and her main victims were children and old people, most vulnerable victims, unable to denounce it or to resist, especially crimes committed in space of private life[5].

From mid-twentieth century and the beginning of this century, crimes are no longer centralized in private space; they make part in the public space and lose the connotation of crimes related to motherhood. Majority of women, between 1998 and 1999 in prison, had committed crimes directed against husbands and partners, and only in the third against children[3]. Prevailed crimes related to drugs, after, crimes, robbery and theft and murder. Crimes committed by women in the period 1999 to 2000, in Rio de Janeiro, were those associated with drugs (use, trafficking and gang formation) in the first place. In second, are the violent crime, murder, infanticide, injuries, thefts, robberies, kidnappings, extortion and violent attacks on decency[5].

Drug trafficking has become the first cause of the imprisonment of wo men of all age groups in Rio de Janeiro in the last 15 years. In 1988, 32.6\% (89 women) of women prisoners in the State of Rio de Janeiro was because of crimes related to drugs, while in 1999 and 2000 the percentage of inmates serving time for the same reason rose to 56\% (294 women). Thus, "between 1988 and 1999/2000, tripled the number of wo men convicted of drug trafficking and did not even double the number of wo men convicted of other crimes"[5].

Theme of women's involvement in drug trafficking has been little explored and little is known about the inclusion of women in this criminal field[4]. Few authors addressed the issue of women in drug trafficking[4,5,8,9,12,13].

The inclusion of women in drug trafficking can occur in two main ways: by boyfriends or more independently. In the latter case, although it does not exclude a participation of male influence, this is not a determinant of entry and continuity in traffic king[4].

The entry of women into trafficking can be due to unemployment, low wages compared to men's wages and the increase of women responsible financially for their families [13]. But also adds the power through crime, easy money and the authority[8].

However, the increase in women prisoners can be due most of women play in trafficking subordinates roles, and more easy captured by police. In decreasing order of frequency and importance the woman roles in the drug trafficking area: "bucha" (person who is arrested for being present in the crime scene); consumers; "mule" or "airplane" (drug carriers); steam (which negotiates small quantities in retail); "an accomplice" or "assistant/fogueteira" (whom warns with fireworks to bandits that the police are coming up). Besides the obvious increase in violence because of drug trafficking in both sexes, there can be a low indulgence on the part of the justice system in relation to the condemnation of wo men[5].

Although the woman can occupy a subordinate position hierarchically in the drug trafficking, this does not exclude the possibility of an important practice of woman in trafficking hierarchy as supplier/distributor, dealer, manager, owner of mouth-to-smoke and cashier/accountant. Currently deserves to be further investigated scientifically the women roles, in the high roles in drug trafficking, because the female violence is increasingly related to drug trafficking.

There is need for further studies on the context surrounding the violence and the woman that receives a little attention when it occupies the headlines newspapers for his performance in crimes, until the male violence robs you of the scene, dis guising the female crimes[5]. These facts point to the need to build public politics for women prisoners. The focus should be on wo men's health in the context of violence, she being a victim or a perpetrator, but above all wo man.

\section{Conclusions}

The literature on gender violence discussed in this paper explains the presence of a strong association of wo man with the condition of the victim, a concept that is influenced by the precepts of the patriarchal society and the decoupling of public-private space. The wo man in the private space would not be able to break with this situation, much less dare to insert themselves in drug trafficking.

The focus should be on denaturalization of the woman as only victims of the violence. The position of aggressor and victim in a gender perspective includes the situation man or wo man in discourse of violence. Both man and woman can be victims and perpetrators. So we avoided generalizations, placing man as perpetrators and woman as victims of violence[6].

We prevent the reproduction an analysis based on victimization, because the roles of victim and aggressor are interchangeable[6,18]. The important is the relationship between man and woman, because "If men and women are victim and/or actor of violence, the focus should then fall on how to build such relationships "[18], an as pect wh ich has not been given due importance in view of the literature on violence and health[11].

The statistics presented show men as the main victims of urban violence, but do not exclude wo men as perpetrators of violence. In fact, women are placed on the margins, especially in drug trafficking, reaching ever more prominent positions.

The inclusion of wo men in drug trafficking rein forces her presence in the field of crime. This should be the object of attention of scholars of gender violence, with greater investments in the subject in order to generate a practice of professional health to care of women in the context of violence, the wo man victim or author of the act of violence.

\section{REFERENCES}

[1] Minayo MCS. Violence: a problem for the health of the Bra- 
zilian. In: Ministério da Saúde (Org.). Violence impact on the health Brazilians. Brasília, Brazil: Ministério da Saúde 2005: 9-33.

[2] Gomes R, MinayoMCS, Silva CFR. Violence against women: a transcultural and transnational issue of gender relations. In: Ministério da Saúde (Org.). Violence impact on the health Brazilians. Brasília, Brazil: Ministério da Saúde 2005: 117-135.

[3] Almeida RO. Women who kill: imaginary universe of crime in the female. Rio de Jan eiro, Brasil: Relume Dumará 2001.

[4] Assis SG, Constantino P. Daughters of the world: female juvenile de linquency in Rio de Janeiro. Rio de Janeiro, Brazil: Fiocruz 2001.

[5] Soares BM, Ilgenfritz I. Prisoners: life and violence behind bars. Rio de Janeiro, Brasil: Garamond 2002.

[6] Gomes R. Women in violent situations from the perspective of health. In: Minay o MCS, Souza ER (Orgs.). Violence from the perspective of health: the contemporary Brazilian infrapolitics. Rio de Janeiro, Brazil: Fiocruz 2003: 199-222.

[7] Frinhani FMD. Imprisoned women: representing the prison environment[Dissertation of Master's degree]. Espírito Santo, Brazil: Federal University of Espírito Santo; 2004.

[8] Guedes MA. Psychosocial interventions in the female prison system. Psicologia ciên cia e profissão. 2006; 26(4): 558-569.

[9] Rita RPS. Mothers and children behind bars: in question the principle of human dignity[Dissertation of Master's degree]. Brasília, Brazil: University of Brasília; 2006.

[10] Braunstein HR. Incarcerated women: the story of outrage and suffering humiliation and acts of violence[Dissertation of Master's degree]. São Paulo, Brazil: University of Sao Paulo; 2007.

[11] Schraiber LB, D'Oliveira AFPL, Couto MT. Violence and health: recent scientific studies. Revista de Saúde Pública. 2006; 40 (special issue): 112-120.

[12] Constantino P. Among the choices and risks, the inclusion of young people in drug trafficking[Dissertation of Master's degree]. Rio de Janeiro, Brazil: National School of Public Health, Oswaldo Cruz Foundation; 2001.

[13] Moki MP. Social representations of female prison[Dissertation of Master's degree]. São Paulo, Brazil: Federal University of Sao Carlos; 2005.

[14] De Souza E, Baldwin JR, Rosa FH. Feminine Sex-Roles Social Construction. Psicologia: reflexão e crítica. 2000; 13(3), 485-496.

[15] Silva COG. Life cycles and integration of young women in situations of risk in Acari[Dissertation of Master's degree]. Rio de Janeiro, Brazil: University Federal Flumin ense; 2005.

[16] Giffin K. Men's entrance into gender studies: contributions of an historical subject. Ciên cia \& Saúde Coletiva. 2005; 10(1), 47-57.

[17] Schraiber LB, Gomes R, Couto MT.Men and health as targets of the Public Health. Ciência \& Saúde Coletiva. 2005; 10(1), $7-17$.

[18] Alvim SF, Souza L. Conjugal violence from a relational perspective: battered/agressors men and women. Psicologia: Teoria e Prática. 2005; 7(2), 171-206.

[19] Almeida VP. Repercussions of the violence in the feminine identity construction of the arrested woman: A case study. Psicologia ciência e profissão. 2006; 26(4), 604-619.

[20] Aquino EML. Gender and health: profile and trends of the scientific production in Brazil. Revista de Saúde Pública. 2006; 40 (special issue), 121-132.

[21] Narvaz MG, Koller HS. Familiesand patriarchy: from normative prescription to creative subversion. Psicologia \& Sociedade. $2006 ; 18(1), 49-55$.

[22] Cortez MB. Domineering husbands, wives (in) subordinate: the implications of female empowerment and hegemonic masculinity in domestic violence[Dissertation of Master's degree]. Espírito Santo, Brazil: Federal University of Espírito Santo; 2006. 